\title{
水プラズマ溶射の特徵とその応用
}

\section{A Characteristic of Water Stabilized Plasma Spraying and the Application}

\author{
中森 正治* \\ Masaharu NAKAMORI
}

Key Words: Thermal Spraying, Water Stabilized Plasma Spraying, Gas Plasma Spraying, TBC, Ceramic Products

\section{1. 諸言}

溶射技術がスイスで誕生して約 100 年、我国へ導入され て約 90 年になる ${ }^{1)}$ が、その間溶射技術は、溶射機、溶射材 料（線材〜粉末まで）、溶射施工機器（ロボット）などの進 歩により著しく進展し、現在では、耐食、耐摩耗を目的と する産業基盤分野から、デジタル、バイオ、環境などのハ イテク分野までいろいろな分野で利用されている ${ }^{2)}$

本報ではプラズマ溶射の一種であるが、作動ガスに冷却 水を蒸気化した水蒸気を利用するという独特の機構を有す る水プラズマ溶射の特徵とその応用例を紹介する。

\section{2. 溶射の種類}

溶射は溶射材料を溶融（半溶融）“溶かす”状態にして 被処理物へ吹き付ける“射＝衝突させる”もので、我国へ 技術導入された際に命名された造語である ${ }^{3)}$ 。(英文では Thermal Spraying と表記される。)

溶射方法はコールドスプレイ ${ }^{4)}$ など現在も新しい方法が 研究開発途上にあるが、汎用されている溶射方法をそのエ ネルギー源より分類すると Table 1 のように整理すること ができる。

Table 1 The thermal spraying methods

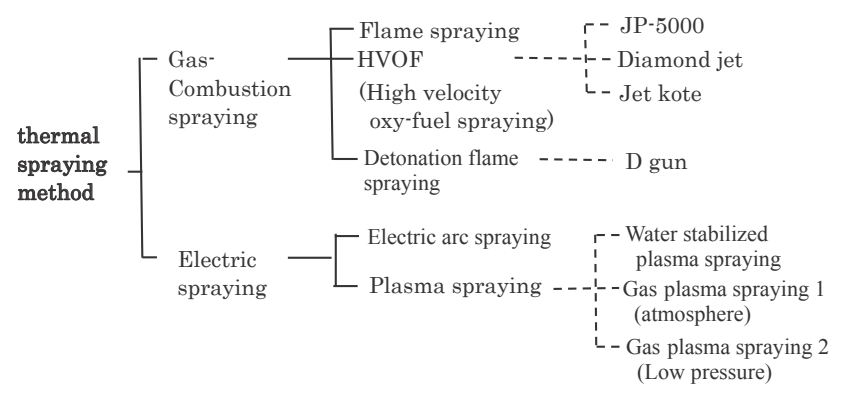

\section{3. 水プラズマ溶射の特徵}

溶射方法の進展は 1960 年代から高温、高速のプラズマ

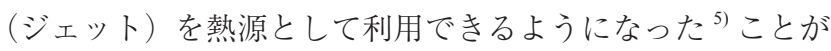
大きく寄与している。この結果、溶射可能な材料は金属か らセラミックまで大幅に広がり、基材との密着性も向上し た。

溶射のためのプラズマ発生方法として、直流（DC）電源 を用いアークを発生させる方法や高周波電磁誘導でプラズ マを発生させる方法が良く知られている ${ }^{6}$ が、通常は DC 電源を用い陰極と陽極がプラズマトーチ内に存在する直流 非移行型と呼ばれる Fig.1の方式が採用されている。

プラズマガスの温度は外部から供給される電気エネル ギーによって容易に変化し、原理的には上限は存在しない が、作動ガスによって保有エネルギーは大きく影響を受け る。作動ガスはアルゴンやへリウム、水素などを使用する のが一般的でガスプラズマ溶射として知られている。一 方、水プラズマ溶射は水をプラズマトーチの冷却として使 用すると共に、その水を蒸気化して作動ガスとする方式で、 1969 年に当時のチェコスロバキアで実用化された ${ }^{7)}$ 。水プ

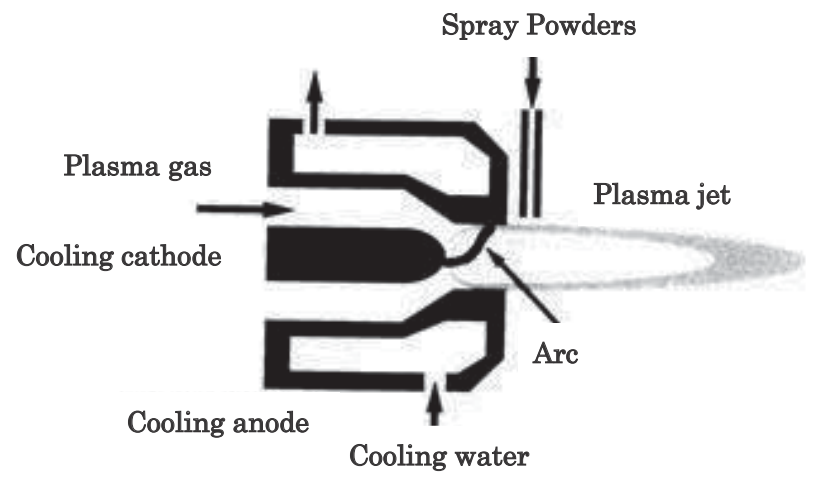

Fig.1 Fundamental structure of DC plasma spraying gun.

*株式会社高温腐食・防食テクノサーチ（％ 676-0082 兵庫県高砂市曾根町 1049-3）

High temperature corrosion \& protection TECHNOSEACH Co., LTD (1049-3 SONE-CHO,TAKASAGO, HYOGO, 676-0082 Japan) 


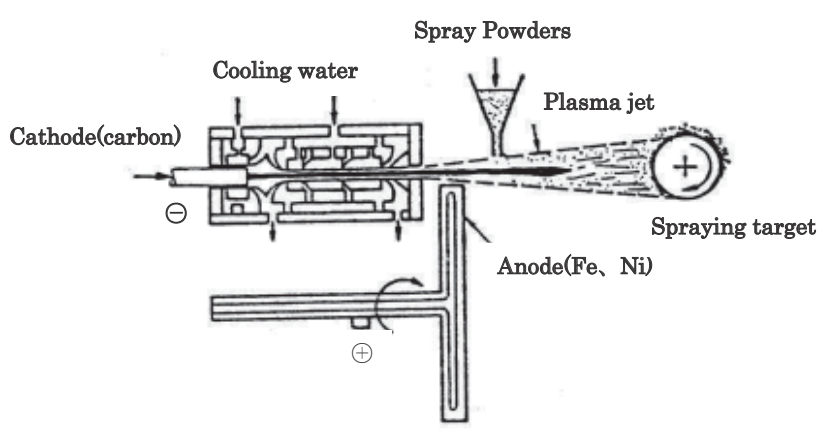

Fig.2 Structure of water stabilized plasma spraying gun.

Table 2 Comparison between gas-plasma spraying and water-stabilizedplasma spraying.

\begin{tabular}{|c|c|c|}
\hline Item & Water stabilized plasma & Gas plasma \\
\hline Spray capacity $(\mathrm{kg} / \mathrm{hr})$ & $10 \sim 30$ & $1.5 \sim 3.5$ \\
\hline Plasma source & $\mathrm{H}_{2} \mathrm{O}$ & $\mathrm{Ar} 、 \mathrm{H} 2 、 \mathrm{~N} 2 、 \mathrm{He}$ \\
\hline Plasma temp. $\left({ }^{\circ} \mathrm{C}\right)$ & $\fallingdotseq 30,000$ & $\fallingdotseq 15,000$ \\
\hline Max. thickness $(\mathrm{mm})$ & $10 \sim 20$ & 1 \\
\hline Spray materials & ceramics & ceramics, metals \\
\hline Spray particle size $(\mu \mathrm{m})$ & $15 \sim 300$ & $15 \sim 45$ \\
\hline
\end{tabular}

ラズマ溶射はこのように高価なアルゴンやへリウム、水素 などのガスを使用せず、溶射できる特徴がある。また、プ ラズマの保有エンタルピーは単原子分子ガス（アルゴン、 ヘリウム)に比較し、二原子分子ガス（水素、窒素）は著 しく大きく、高い加熱能力を有することが知られている ${ }^{8)}$ が、水 $\left(\mathrm{H}_{2} \mathrm{O}\right)$ は三原子分子として、 $\mathrm{H}_{2}$ と $\mathrm{O}$ に解離後、さ らに $\mathrm{H}_{2}$ が $\mathrm{H}$ 原子に解離し、その後電離するため、保有工 ンタルピーは高く、電力投入量に比例して高い火炎温度（公 称 $30,000{ }^{\circ} \mathrm{C}$ ） が得られる ${ }^{9)}$ 。一方、アルゴンやヘリウムを 使用する通常のガスプラズマ溶射の火炎温度はおよそ5,000 ${ }^{\circ} \mathrm{C}$ から $10,000{ }^{\circ} \mathrm{C}$ である ${ }^{10)}$ 。

水プラズマ溶射はこのように水をプラズマトーチの泠却 と作動ガスとするため、ガスプラズマ溶射装置と同様、直 流非移行型プラズマ発生装置の一種であるが、ガスプラズ マ溶射装置に比較し特徵ある構造となっている。

Fig.2にプラズマトーチの基本構造を示したが、㓌極は カーボン、陽極は鉄またはニッケルで作られており、陰極 と陽極間で発生させる直流アークにより、水蒸気を電離し プラズマジェットを作る。この時陽極は局所的な消耗を避 けるため、内部水冷すると同時に回転させる。水と直流アー クの間に隔膜があり、この膜を通りアークにより加熱され た水蒸気が通過し、直流アークを囲む渦流となり、これが 電離してプラズマジェットを形成する構造になっている。 Table 2 にガスプラズマ溶射と水プラズマ溶射の主仕様を 比較した。

\section{4. 水プラズマ溶射の応用例}

水蒸気を作動ガスとした結果、プラズマガスは温度が著 しく高くなるが、水蒸気の分解で生じた水素と酸素が共存 するため、金属溶射材料は酸化する可能性があり、現在の ところ酸化物系セラミックスが主な溶射材料として使用さ れている。

\section{以下では水プラズマ溶射の応用例を紹介する。}

(1) TBC (Thermal barrier coating : 遮熱コーティング $)^{11)}$

$\mathrm{TBC}$ は高温然焼ガス中で使用される金属材料を保護する 目的で熱伝導率が低く、耐熱性のあるセラミックを表面処 理するもので、1970 年代にNASA で盛んに研究され、ほ ぼ現在のコンセプトは確立された ${ }^{12)}$ 。一方、ガスタービ ンは高効率発電用コンバインドプラントの主要機器として の発展は著しく、新鋭プラントのガスタービン入口温度は $1500^{\circ} \mathrm{C}$ 以上となり、このような高温燃焼ガス中で使用され る燃焼器や動静翼は内部を空気 (一部水蒸気) で泠却して 使用されているが、燃焼ガス側の表面に TBC を施工するこ とが必須の技術となっている ${ }^{13)}$ 。

ガスタービンへ適用される $\mathrm{TBC}$ は、最外層は $\mathrm{ZrO}_{2}-8$ mass $\% \mathrm{Y}_{2} \mathrm{O}_{3}$ (以下、 $\mathrm{ZrO}_{2}-\mathrm{Y}_{2} \mathrm{O}_{3}$ ) で、ボンドコートを Co$35 \mathrm{Ni}-21 \mathrm{Cr}-8 \mathrm{Al}-0.5 \mathrm{Y}$ 合金（mass\%、以下 $\mathrm{CoNiCrAlY}$ ）とし、 それぞれガスプラズマ溶射及び低圧プラズマ溶射（低圧不 活性ガス中でのプラズマ溶射）または高速フレーム溶射 (HVOF）で施工するのが一般的である ${ }^{14)}$

本報ではこの最外層のガスプラズマ溶射による $\mathrm{ZrO}_{2}$ $\mathrm{Y}_{2} \mathrm{O}_{3}$ 施工を水プラズマ溶射へ変更を検討した結果を紹介す る。

\section{(1)試験片の作成}

皮膜性能を調査するため、耐熱ステンレス SUS310S 鋼管 $(\mathrm{Fe}-25 \mathrm{Cr}-20 \mathrm{Ni} 、 \mathrm{mass} \% 、 \phi 27 \times 100 \mathrm{~L} \times 4 \mathrm{t} \mathrm{mm})$ ح Table 3 の仕様で、ボンドコートに HVOF（TAFA 社 JP-5000）で CoNiCrAlY を $100 \mu \mathrm{m}$ 厚さ目標に溶射し、その後トップコー トに水プラズマ（アクセントラム社）で $\mathrm{ZrO}_{2}-\mathrm{Y}_{2} \mathrm{O}_{3}$ [中空 球形粉（Spheroidal/Hollow）および溶融粉砕粉（Fused and crushed)] $0.3 \mathrm{~mm}$ から $1.4 \mathrm{~mm}$ 厚さに変化させたものを 作成した。(以下 WPS-TBC と記す)

さらにTable 3 に併記したように比較試験片として HVOF C゙ CoNiCrAlYを溶射後、トップコートをガスプラ ズマ溶射（スルーザーメテコ社 A-3000S）で中空球形粉の $\mathrm{ZrO}_{2}-\mathrm{Y}_{2} \mathrm{O}_{3}$ を $0.3 \mathrm{~mm}$ から $1.4 \mathrm{~mm}$ 厚さに溶射したものを作 製した。(以下 APS-TBC と記す)

作製した各試験片はいずれもクラックや剥離などの異常 はなく、健全な外観状態であった。Fig.3に各試験片の代 表的な断面皮膜組織を示したが、HVOF 溶射組織は緻密で あるが組織中には未溶融溶射粒子が認められた。またガス プラズマ溶射による $\mathrm{ZrO}_{2}-\mathrm{Y}_{2} \mathrm{O}_{3}$ 溶射層は多数の空孔が認め られるのに対し水プラズマ溶射による $\mathrm{ZrO}_{2}-\mathrm{Y}_{2} \mathrm{O}_{3}$ 溶射層は 
Table 3 Specification of tested TBC system Specimens.

\begin{tabular}{|c|c|c|}
\hline Powders & Spray methods & Thickness (mm) \\
\hline Spheroidal/Hollow*1 & W P S & $0.3,0.5,0.8,1.2$ \\
\hline Fused and crushed ${ }^{* 2}$ & W P S & $0.3,0.5,0.8,1.4$ \\
\hline Spheroidal/Hollow ${ }^{* 1}$ & APS & $0.3,0.5,0.8,1.2$ \\
\hline
\end{tabular}

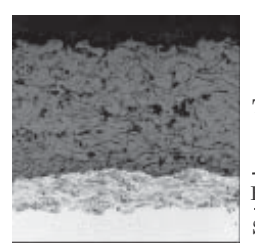

WPS(SH)/HVOF

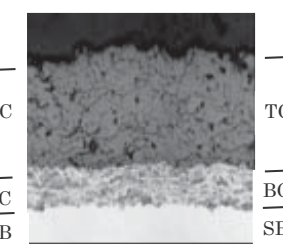

WPS(FC)/HVOF

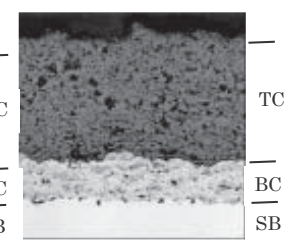

$\mathrm{APS}(\mathrm{SH}) / \mathrm{HV0} \mu \mathrm{m}$
Fig.3 Cross-sectional microstructure of TBC systems before thermal cycles test.

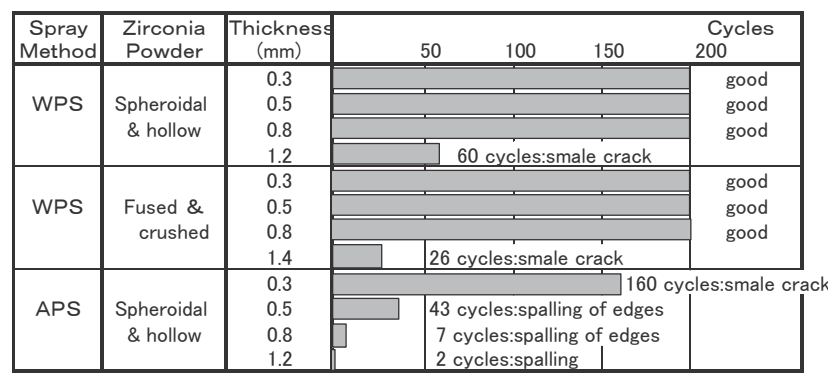

Fig.4 Results on thermal cycle test for TBC system specimens.

中空球形粉および溶融粉砕粉ともほぼ近似した組織で空孔 と微小なクラックが混在していた。

(2)耐熱サイクル性

$\mathrm{TBC}$ (セラミック層) の耐熱サイクル性は実用時を考慮 すると非常に重要な評価項目となるため、電気炉を利用し 大気雲囲気中で $1000{ }^{\circ} \mathrm{C} 、 20$ 分間保持後、炬より取出すと 同時に送風機により室温まで強制冷却（1000 ${ }^{\circ} \mathrm{C} \sim 200{ }^{\circ} \mathrm{C} /$ $5 \mathrm{~min} 、 200{ }^{\circ} \mathrm{C} \sim \mathrm{RT} /$ 約 $2 \mathrm{Hr}$ ) する操作を 1 サイクルとし、 200 サイクルを目標とする熱サイクル試験を実施した。

試験中、各試験片はサイクル終了毎に目視による観察を 行い、皮膜の割れや剥離等が発生したサイクル数を記録す るとともにその進展状況を観察した。

Fig.4に試験結果をとりまとめて示したが、APS-TBC 試 験片はトップコート厚さ $1.2 \mathrm{~mm}$ が 2 サイクル終了後（以 下全てサイクル終了時)、0.8 mm が7サイクル、0.5 mm が 43 サイクル、0.3 mm が 160 サイクルとトップコートが厚

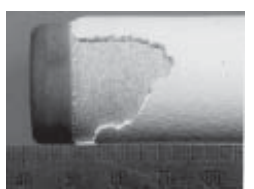

(a)WPS(SC)/HVOF

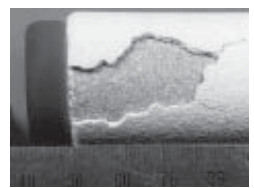

(b)WPS(FC)/HVOF

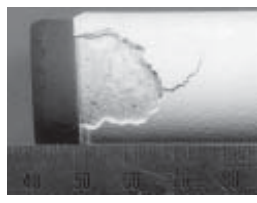

(c)APS(SC)/HVOF
Fig.5 Typical failure of TBC systems after thermal cycles test.

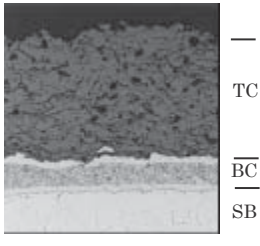

WPS(SH)/HVOF

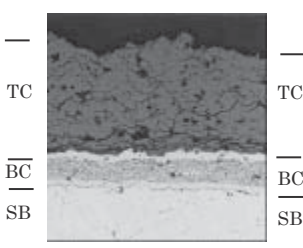

WPS(FC)/HVOF

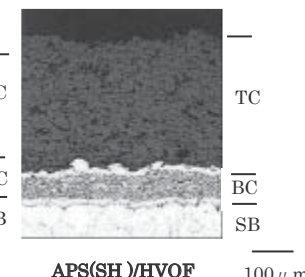

$\operatorname{APS}(\mathrm{SH}) / \mathrm{HVOF} \quad \overline{100 \mu \mathrm{m}}$
Fig.6 Cross-sectional microstructure of TBC coatings after thermal cycles test.

いほど早い段階で溶射端部から局所的な剥離が発生し、そ の後ヒートサイクルの増加とともに剥離面積は拡大してい く傾向を示した。一方、WPS-TBC 試験片は中空球形粉お よび溶融粉砕粉ともに、トップコート厚さ $1.2 \sim 1.4 \mathrm{~mm}$ で それぞれ 40 サイクルと 26 サイクルで試験片の溶射端部で 小剥離が発生したが、膜厚 $0.8 \mathrm{~mm}$ 以下ではいずれも 200 サイクル終了後もクラックや剥離の異常は認められず、優 れた耐熱サイクル性を示した。

Fig.5 にクラックや剥離を生じた試験片の代表的な外観 状況を剥離で浮き上った溶射層を強制的にはがした状態で 示した。観察の結果、熱サイクルによる剥離はAPS-TBC、 WPS-TBCいずれもボンドコート（合金層）とトップコー ト (ジルコニア層) の界面で生じており、ボンドコート側 にわずかにジルコニアの残留が認められた。

またAPS-TBCの場合、いったん発生したクラックはそ の後の熱サイクルにより容易に進展する傾向を示したのに 対し、WPS-TBCでは 200 回の熱サイクル試験終了後もほ ぼ初期の損傷状態と同状態であり、クラックや剥離の進展 は遅いことが確認された。

Fig.6に熱サイクル試験後の試験片（トップコート厚さ： $0.3 \mathrm{~mm}$ ）のジルコニア溶射層の代表的な断面皮膜組織を示 したが、WPS-TBC、APS-TBCともにジルコニア層自体に は試験前と比較し顕著な変化は見られなかった。

以上のように WPS-TBC は APS-TBC に比較しトップコー トのジルコニア層が同等膜厚の場合はもちろん、ジルコニ ア層を厚くした場合でも耐熱サイクル性が優れていた。ま たAPS の場合、中空球形粉に比較しやや溶射性に難点があ り、耐熱サイクル性も劣る溶融粉砕粉でも、WPS の場合は 
中空球形粉と同等の耐熱サイクル性を有することが確認さ れた。

WPS-TBC はAPS-TBCに比較し優れた耐熱サイクル性を 示した原因は、APSによるジルコニア溶射層組織は小さな 空孔が分散しているのに対し、WPS ジルコニア層は溶融状 態の扁平粒子が積層した様相を呈し、その粒子相互の間に は空孔とともに、多数の小クラックが混在しており、熱サ イクル試験ではこのクラックが加熱・冷却にともなって発 生する応力を緩和している可能性が大きい。また、このよ うな組織的特徵の結果、応力負荷試験では WPS-TBC に生 じたクラックは、内在する微小クラックと合体しながらジ グザグに進展して、全体的に APS-TBCに比較し、クラッ クの進展が遅延される傾向にあった ${ }^{15)}$ 。

$\mathrm{TBC}$ の遮熱効果は次の式 ${ }^{16)}$ で示される通り、セラミック の熱伝導率とその厚さに大きく依存している。

$\mathrm{R}=\left(1 / \alpha_{\mathrm{g}}\right)+\left(\mathrm{t}_{\mathrm{ce}} / \lambda_{\mathrm{ce}}\right)+\left(\mathrm{t}_{\mathrm{b}} / \lambda_{\mathrm{b}}\right)+\left(\mathrm{t}_{\mathrm{s}} / \lambda_{\mathrm{s}}\right)+\left(1 / \alpha_{\mathrm{c}}\right)$

ここで $\mathrm{R}$ : 熱抵抗、 $\mathrm{t}$ : 厚さ、 $a$ : 熱伝達率、 $\lambda$ : 熱伝導率、 添字 g、ce、b、s、c はそれぞれ高温ガス、セラミック、ボンド コート合金、基材合金、冷却ガスをあらわす。

(1) 式からも明らかなように、セラミックトップコート の組成や性質が同一であればその厚さが増すほど遮熱効果 は大きく、この点からも厚膜化が可能な WPS-TBC はAPS$\mathrm{TBC}$ に比較し、有利である。

(2) 製紙用ロールへのセラミック溶射

製紙用機械は「その殆どがロールでできている。」と言わ れるように多くのロールがいろいろな表面処理を行い、そ れぞれ異なる環境で使用されている。

セラミック溶射はゴムライニングや花崗岩ロール（ワイ ヤロール、プレスロールなど）に対する耐久性や処理コス 卜低減の面から採用され、特に水プラズマ溶射は比較的安 価に厚膜が施工可能なことから、Fig.7のように大型ロー ルを中心に耐食合金の下地溶射皮膜上に、アルミナ系溶射

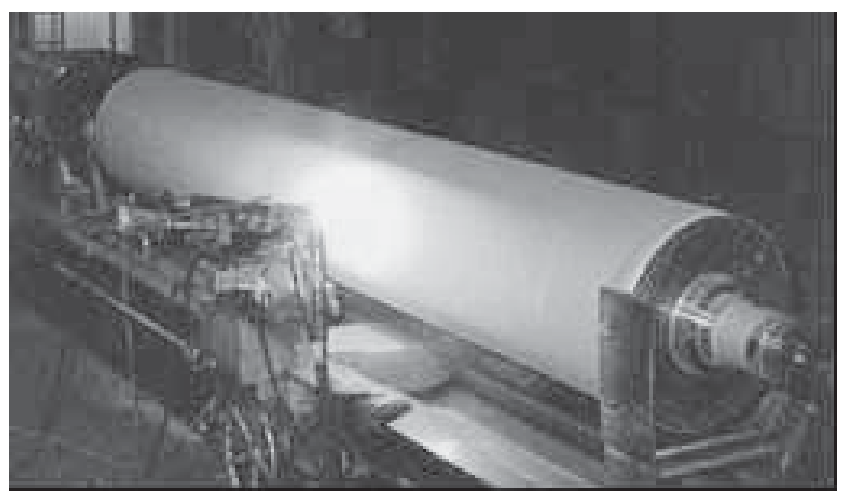

Fig.7 Water stabilized plasma spraying to roll for paper machine.
材料を数 $\mathrm{mm}$ 程度上盛し使用されている。

(3) 電子部品焼成用耐火物へのセラミック溶射 ${ }^{17)}$

電子工業部品と呼ばれるコンデンサーやインダクター、 フェライト、バリスタなどは、自動車や家電製品、パソコン、 携帯電話など、身近な製品の中にも多くも用いられている。

これらの部品はいったん成形した後に焼成処理を行うこ とで所定の電気的特性が得られる。焼成処理は耐火物でで きた棚板に電気部品を載せて電気炉内で行うが、そのまま 焼成すると耐火物に含まれるシリカ成分などの不純物が電 子部品を污染して電気的特性を阻害するため、歩留まりが 著しく低下する。従来は高純度のセラミック粉を敷き粉と して用いたり、高純度セラミックシートが用いられてきた が、焼成処理ごとに敷き直したり、取り替えたりする必要 がある。また、ケース状の耐火物では側面に敷き粉が適用 できないなど、不便な点が多かった。現在は水プラズマ溶 射でアルミナ $\left(\mathrm{Al}_{2} \mathrm{O}_{3}\right)$ やジルコニア $\left(\mathrm{ZrO}_{2}\right)$ などを主成分と するセラミックを溶射する仕様が規格化されている。

(4) 電子部品原料粉末製造用ロータリキルンパイプの製造 前項までは表面処理として水プラズマ溶射の応用を紹介 したが、水プラズマ溶射方法が開発された当初は大型のセ ラミックパイプを製造することも目的の一つであり、現在 も WAPLOC という商品名で Fig.8のような様々な形状の製

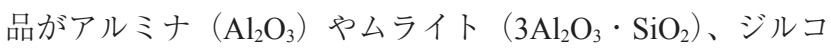
ン $\left(\mathrm{ZrO}_{2} \cdot \mathrm{SiO}_{2}\right)$ などのセラミックにより製造されている。 本報で紹介する電子部品原料粉末焼成用ロータリキルンパ イプの製造はこの水プラズマ溶射による成形性を利用した ものである。

一般に、電子工業部品の原料となるチタン酸バリウムな どは原料粉末の焼成処理を経て供給されるが、焼成工程の 効率化を図るために大型の連続式回転熱処理炉が用いられ ている。この回転熱処理炉の炉芯管はロータリキルンパイ

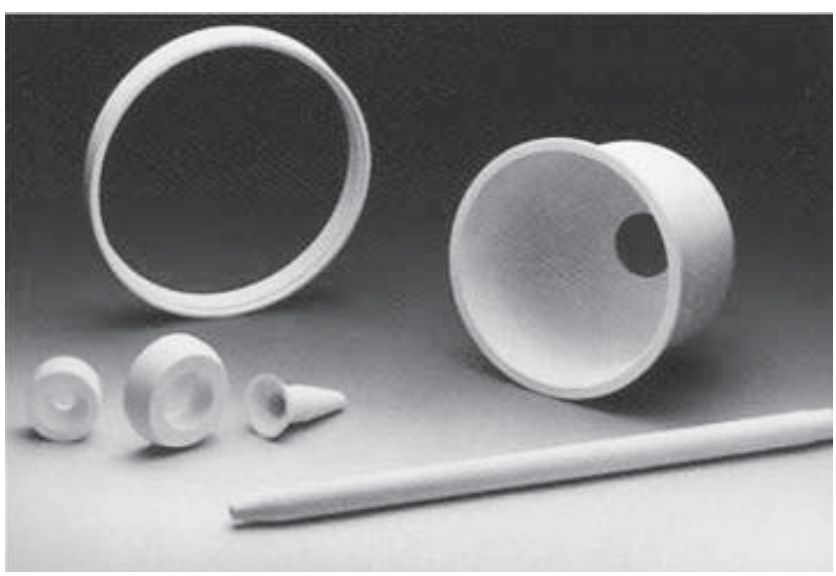

Fig.8 Ceramic products which made Water stabilized plasma spraying. 
プとも呼ばれ、金属性パイプでは原料を污染する問題があ り、また焼結セラミックでは大型パイプの製作が困難で、 使用時の熱衝撃などで破損する可能性もあることから熱衝 撃性に優れた水プラズマ溶射によるセラミックパイプが採 用されている。セラミックパイプは一度金属製炉芯金型に 溶射した後、セラミックだけをパイプとして抜き取ること によって製造されている。

\section{5. あとがき}

以上、水プラズマ溶射の特徴とその応用例を紹介した。 水プラズマ溶射は発明地が東欧（現チェコ共和国）という こともあり、ガスプラズマ溶射に比較するとその認知度も 低く、その後の技術的進展、応用も十分とは言えないが、 水をプラズマトーチの冷却と同時に蒸気化して作動ガスと して利用する手法は溶射以外への展開も大いに感じさせ る。

現にチェコ共和国プラハのプラズマ物理研究所ではいく つかの興味ある研究成果が発表 ${ }^{18)}$ されており今後の進展が 大いに期待される。

最後に、水プラズマ溶射の応用紹介に使用した写真の一 部は大阪富士工業株式会社から、提供されたものであり、 記して感謝致します。

\section{引用文献}

1）日本溶射協会偏：溶射技術ハンドブック、(1998) 3.
2) 谷 和美、中平 晃：溶射、44-4, (2007) 96-102

3) 日本溶射協会偏：溶射ハンドブック、(1987) 3 .

4) 榊 和彦: 溶射、44-4, (2007) 111-113

5) 例えば、蓮井 淳、北原 繁：日本溶射誌、2-1,(1964) 50 .

6）沖 幸男：表面技術、49-6, (1998) 44-51.

7) 日本溶射協会偏：溶射ハンドブック、(1987) 152-154.

8) 袖田 賢：溶射、41-3, (2004) 120-125

9) 大割健男：金属、81-2, (1981) 1-4.

10) A. Vardelle. J. M. Baronnel. M. Vardelle and P. Fauchais : IEEE Transact on PS-8, (1989) 417.

11) 中森正治、相坂隆行、吉川文人:材料と環境、52-12, (200)650-655.

12) 例えば、P, E, Hodge, S, Stecure, M, A, Gedwill, I, Zaplatynsky and S. R. Levine : DOE / NASA / 2593-78/3, NASA TM-79005, October (1978).

13）岩崎洋一、北内洋介、屋敷光一郎、塚原章友: 火力原子力発電、 59-10, (2008) 61-67.

14) Kh. G. Schmitt-Thomas, H. Haindl, D. Fu : Surface and Technology, 94-95, (1997) 149-154.

15) T. Takahashi, M. Yoshiba and M. Nakamori, MECJ-02, II,(2002) 211.

16) M. Yoshiba, GTSJ, 28, 4, (2002) 135.

17）相坂隆行、吉川文人、中森正治: 日刊工業新聞、溶射特集記事、 (2006).

18）例 えば、Brozek V., Hrabovsky M., Kopecky V. : Decomposition of polyhalogenide hydrocarbons in plasma jet generated by water stabilized plasma torch. High Temperature Material Processes 3 (1999) 375-384. 